\title{
Repatriation of Polish refugees of World War I: the case of the Altai Province
}

\author{
Yurii M. Goncharov ${ }^{\mathrm{a}}{ }^{\square}$, Ksenia A. Tishkina ${ }^{b}$ \\ a Altay State University, Barnaul, Russia \\ b Siberian Federal University, Krasnoyarsk, Russia \\ $\checkmark$ yuriig@yandex.ru
}

\begin{abstract}
During World War I a large number of refugees evacuated to the Russian Empire's periphery, such as the many Poles who were temporarily transported eastward to Siberia. This article studies their repatriation after the conflict's end, which bears some relevance to forced migration, refugees and repatriation in today's world. Based on archival and secondary sources, the authors endeavor to reconstruct the repatriation of Polish refugees from Altai province in southern Siberia. Beginning in earnest after the Soviet Union's war with Poland of 1918-21, their return was hampered by the difficult conditions of the past Civil War and the country's economic crisis. Although an extensive network of organizations was set up to carry the repatriation out, poor communication with the center, insufficient staff and the absence of registration forms made its work extremely difficult. At the same time, many refugees returned on their own, which further complicated matters. Nevertheless, most Poles eventually made it back home. The Russian-Ukrainian-Polish Mixed Commission on Repatriation announced that its work was done in 1924, although in fact it lasted for another year.
\end{abstract}

Keywords: Siberia, Altai province, The Furst World War, Poles, refugees, repatriation

Acknowledgements and Funding: The study was funded by RFBR and BRFBR, project number 20-59-00010 "Ethnic minorities in Belarus and Russia in the conditions of social transformations of the XIX-XX centuries" and by RFBR, project number 19-39-60009 "Siberian public and organization of assistance to victims of wars of the early XX century."

For citation: Goncharov, Yurii M., and Tishkina, Ksenia A. "Repatriation of Polish refugees of World War I: the case of the Altai Province." RUDN Journal of Russian History 20, no. 4 (November 2021): 508-516. https://doi.org/10.22363/2312-8674-2021-20-4-508-516

\section{Репатриация польских беженцев Первой мировой войны: на примере Алтайской губернии}

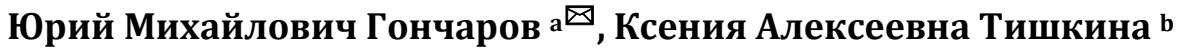

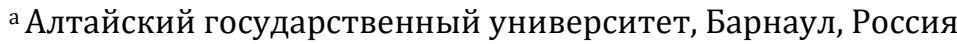 \\ b Сибирский федеральный университет, Красноярск, Россия \\ $\checkmark$ yuriig@yandex.ru
}

\begin{abstract}
Аннотация: Одним из последствий участия Российской империи в Первой мировой войне явился значительный поток беженцев, эвакуированных на окраины страны. Значительное число поляков было эвакуировано в Сибирь. Статья посвящена рассмотрению процесса репатриации беженцев Первой мировой войны из Сибири в Польшу. Актуальность работы определяется важностью проблем вынужденных мигрантов, беженцев и репатриантов в современном мире. Работа основана на архивных источниках и опубликованных документах, на основе анализа которых предпринята попытка реконструкции процедуры репатриации польских беженцев из Алтайской
\end{abstract}

(C) Goncharov Yu.M., Tishkina K.A., 2021

(c) (i) This work is licensed under a Creative Commons Attribution 4.0 International License https://creativecommons.org/licenses/by/4.0/ 
губернии. Процесс репатриации активизировался после заключения мирного договора Советской Россией с Украиной и Польшей весной 1921 г. Репатриация польских беженцев Первой мировой войны, поселившихся на территории Сибири, осуществлялась в тяжелых условиях прошедшей Гражданской войны и экономическим кризисом в стране. Несмотря на создание целой сети органов по контролю над эвакуацией населения, на практике их работа выполнялась крайне неэффективно из-за плохого информирования центра, малочисленности сотрудников, отсутствия бланков регистрации беженцев. Многие беженцы самовольно покидали населенные пункты, что затрудняло учет вынужденных мигрантов. Тем не менее, большинство польских беженцев в итоге были отправлены на родину. Об окончании массовой репатриации в Польшу было объявлено в 1924 г. после завершения деятельности Российско-украинско-польской Смешанной комиссии по делам репатриации, однако работа по репатриации растянулась до конца 1925 г.

Ключевые слова: Сибирь, Алтайская губерния, Первая мировая война, поляки, беженцы, репатриация

Благодарности и финансирование: Исследование выполнено при финансовой поддержке РФФИ и БРФФИ в рамках научного проекта № 20-59-00010 «Этнические меньшинства в Беларуси и России в условиях общественных трансформаций XIX-XX вв.» и при финансовой поддержке РФФИ в рамках научного проекта № 19-39-60009 «Сибирская общественность и организация помощи жертвам войн начала XX века».

Для цитирования: Goncharov Yu.M, Tishkina K.A. Repatriation of Polish refugees of World War I: the case of the Altai Province // Вестник Российского университета дружбы народов. Серия: История России. 2021. Т. 20. № 4. С. 508-516. https://doi.org/10.22363/2312-8674-2021-20-4-508-516

\section{Introduction}

Over the past few decades, historians have increasingly paid attention to the Russian Empire's many ethnic minorities. Because of its unique history as home to a number of diasporas from European Russia, Siberia is of particular interest in this respect. Among the nationalities that resettled across the Ural Mountains, the Poles played an important role. ${ }^{1}$ Scholars have long studied this group, ${ }^{2}$ paying attention to such questions as sources, demographic processes, family, ${ }^{3}$ the role of Poles in developing the region, adaptation in the host community, ${ }^{4}$ etc. ${ }^{5}$

Because of its relevance to current events, the history of the repatriation of Polish refugees and prisoners of war from Siberia after the end of the First World War is an important chapter in the broader story. ${ }^{6}$ Studying the mechanisms of repatriation, as well as the role of the repatriates' own wishes, allows us to apply past experience to modern realities. Both Polish historians ${ }^{7}$ and their Russian colleagues, including regional ones, have done much work on the matter. ${ }^{8}$

${ }^{1}$ V.N. Shaidurov, "Ethnic Entrepreneurship in the Russian Empire in the Era of Economic Modernization in the Second Half of the $19^{\text {th }}-$ Early $20^{\text {th }}$ century (as Illustrated in the Example of Siberia)," Bylye gody, no. 3 (2016): 666-674; V.N. Shaidurov, "On the emerging polish diaspora and its development in Siberia in the first half of the $19^{\text {th }}$ Century," Journal of Siberian Federal University. Humanities \& Social Sciences, no. 10 (2016): 2496-2506.

2 B.S. Shostakovich, "Sistemnaya sibirsko-pol'skaya istoriya - sovremennaya kontseptual'naya al'ternativa marginal'no-traditsionalisticheskogo diskursa istorii polyakov v Sibiri." In Pol'skie ssyl'nye v Sibiri vo vtoroi polovine XVIII - nachale XX veka v vospriyatii rossiiskoi administratsii, pereselentsev $i$ korennykh narodov Sibiri (Omsk: Poligraf tsentr KAN Publ., 2015), 10-22.

3 Jurij M. Gonczarow, "Polska rodzina na Syberii w połowine XIX i na początku XX wieku," Zestaniec, no. 29 (2007): 33-48.

${ }^{4}$ V.N. Shaidurov, "The Polish community in Western Siberia: Adaption and integration features in the second half of the $19^{\text {th }}$ century," Acta Histriae 26, no. 2 (2018): 641-660.

${ }^{5}$ V.A. Skubnevskii, and Yu.M. Goncharov, "Polyaki v Sibiri (XIX - nachala XX v.) v osveshchenii postsovetskoi otechestvennoi istoriografii," Vestnik Tomskogo gosudarstvennogo universiteta. Istoriya, no. 69 (2021): 162-170.

${ }^{6}$ P. Gatrell, "Refugee history and refugees during and after The First World War," Vestnik of Saint Petersburg University. History 62, no. 3 (2017): 497-521.

${ }^{7}$ D. Sula, Powrót ludności polskiej: z bytego Imperium Rosyjskiego w latach 1918-1937 (Warszawa: [N.s.], 2013).

${ }^{8}$ N.V. Lakhareva, Reevakuatsyia bezhentsev Pervoi mirovoi voiny s territorii Kurskoi gubernii (1918-1925) (Kursk: KIGMS Publ., 2001). 
I.B. Belova made a significant contribution to the field by reconstructing the stepby-step process of repatriating war refugees of different nationalities from Soviet Russia, ${ }^{9}$ while I.V. Nam paid particular attention to the forced movement of Poles in the difficult conditions of the Civil War ${ }^{10}$ Mobilizing a wide range of archival materials, L.K. Ostrovskii considered repatriation in the context of the restoration of Soviet power in Siberia. ${ }^{11}$ And R.V. Oplakanskaia focused on the Russian-Ukrainian-Polish Mixed Commission for Repatriation in Siberia. ${ }^{12}$ But when it comes to Russian regional history, the study of repatriating Polish war refugees is still at a very early stage. In this regard, the experience Altai province, which existed as an independent administrative-territorial unit until May 25,1925 , is of interest.

The objective of this article is to reconstruct the mechanisms of organizing the repatriation of Polish refugees of the First World War in Altai for the first time. The authors have based their research on a wide range of sources, including documents from regional archives, namely the State Archives of Altai Krai, Novosibirsk Region and Tomsk Region. The newspapers Altaiskaia Mysl, Krasny Altai, and Sovetskaia Sibir' also proved to be valuable sources.

\section{Polish Repatriation in 1918-1919}

Refugees from the Russian Empire's western provinces began to arrive in Siberia in large numbers in fall 1915. Almost immediately upon reaching their destination, some forced migrants submitted requests to local authorities for a possible return to their homeland, but due to the unstable situation at the front and inside the country, they were not granted.

Polish refugees constituted the second largest group of forced migrants after Russians (including Belarusians and Ukrainians) during the Great War. Already in April 1916, the Barnaul Department of the Polish Society for Aid to War Victims informed Petrograd about 100 families of Polish refugees. ${ }^{13}$ As of September 1, 1916, out of 32,318 refugees registered in Tomsk province and under the care of the city committees for aid to refugees 3,245 were Poles. ${ }^{14}$

After the Revolution in 1917 and the signing of the Brest-Litovsk peace treaty in spring 1918, returning the war refugees to their homeland began to attract the attention of Moscow, where in April 1918, the Central Collegium for Prisoner of War and Refugee Affairs (Tsetroplenbezh), opened its doors. However, since the Bolsheviks were not yet in control of Siberia at the time, retuning the region's forced migrants was out of the question.

After the establishment of the Republic of Poland in November 1918, returning refugees to their homeland once again became relevant. Thus, in spring 1919 in Barnaul,

${ }^{9}$ I.B Belova, "First World War refugees' situation in Soviet Russia: 1921," Historical, philosophical, political and law sciences, culturology and study of art. Issues of theory and practice 18, no. 4-2 (2012): 26-29; I.B Belova, "Refugees of the First World War in Soviet Russia 1918-1919," Gumanitarnye nauki v Sibiri, no. 3 (2014): 32-36; I.B Belova, Vynuzhdennye migranty: bezhentsy $i$ voennoplennye Pervoi mirovoi voiny $v$ Rossii. 1914-1925 (Moscow: AIRO-XXI Publ., 2014).

${ }^{10}$ I.V. Nam, "Pol'skie bezhentsy Pervoi mirovoi voiny v Sibiri." In Pol'skie ssyl'nye v Sibiri vo vtoroi polovine XVIII - nachale XX veka v vospriyatii rossiiskoi administratsii, pereselentsev $i$ korennykh narodov Sibiri (Omsk: Poligraf Tsentr KAN Publ., 2015); Nam, I.V. Natsional'nye men'shinstva Sibiri i Dal'nego Vostoka na istoricheskom perelome (1917-1922 gg.) (Tomsk: Tomsk university Pabl., 2009).

${ }^{11}$ L.K. Ostrovskii, Poliaki v Zapadnoi Sibiri v kontse XIX-pervoi chetverti XX veka (St. Petersburg: Aleteia Publ., 2018); L.K. Ostrovskii, "Repatriatsiya optantov, bezhentsev i voennoplennykh iz Sibiri v Pol'shu (1921-1924 gg.).” Gumanitarnye nauki v Sibiri, no. 3 (2014): 70-74.

12 R.V. Oplakanskaia, "Deiatel'nost' predstavitel'stva Smeshannoi komissii v Sibiri po repatriatsii pol'skikh voennoplennykh v 1921 godu." Tomskii zhurnal LING i ANTR, no. 3 (2015): 120-127.

${ }^{13}$ L.K. Ostrovskii, Polyaki v Zapadnoi Sibiri, 199.

${ }^{14}$ Gosudastvennyi arkhiv Tomskoi oblasti (henceforth GATO), f. 7, op. 1, d. 5, 1. 54a. 
the Bureau for Aid to Refugees at the Altai Provincial Zemstvo Council, which included representatives of the city's national organizations, was set up. The interests of the Poles were represented by a member of the Polish Military Committee in Siberia, Lieutenant $\mathrm{K}$. Viakovskii. The Bureau's main task was to register all refugees in the province to organize their re-evacuation. To this end, it drew up a questionnaire to record basic details about a refugee, such as his name, his original home, whether he intends to return there, etc. ${ }^{15}$

On March 4, 1919, the Council of People's Commissars issued a decree "On the conscription of certain categories of the urban population," followed by a supplement on March 20, "On exemption from conscription of persons of Polish nationality in the event of their withdrawal from Russian citizenship." It stated that all Poles of Russian citizenship who wanted to join the ranks of Polish citizens were to submit a written application to the People's Commissariat of Internal Affairs to change their citizenship within a week. Registration began that spring in Siberian cities, and Poles who had participated in the 1863 uprising, political exiles, refugees, the disabled, and members of the families of those who had been mobilized were also invited to submit their names. ${ }^{16}$

With the establishment of Soviet power in Siberia, the question repatriating the war refugees was raised again. Thus, starting in December 1919, Tsetroplenbezh set up offices in the provinces. In early January 1920, the Plenbezh department (Collegium for Prisoner of War and Refugee Affairs) of the Altai Gubrevkom created a special collegium which included representatives of various factions of refugees. At the end of January 1920, volost revolutionary committees and rural executive committees instructed the collegium to conduct a census of all World War I refugees living in Altai province. In Barnaul, the forced migrants were to be registered between January 27 and February 15, 1920. The details that were gathered were to be used to draw up a work plan for their re-evacuation. However, the migrants were informed that

...sending them to their homeland is not expected in the near future and it is unlikely to take place before the spring, due to the transport problems and the typhus epidemic. ${ }^{17}$

When the Plenbezh department began its work, refugees who wanted to leave hastened to submit their applications, which indicated their plight, particularly in rural areas, lack of work, housing, refusal to be assigned land plots, etc. Cash benefits were paid only in emergency situations, such as for example, a funeral, the birth of a child, an illness, etc.,

...in all other cases, refugees got in-kind aid rather than cash benefits. ${ }^{18}$

The refugees were not afraid of the martial law that had been imposed in the country's west. For example, the collective request of the forced migrants living in the village of Romanovo, Zimovsk volost, as recorded by local refugee commissioner P. Evdiuk, decreed:

If some provinces are occupied by the Bolsheviks, they are ready to go, although it will be worse there. However, if they agree to go, they must say that they will go home; sow enough grain for both themselves and the Government rather than work for other people, move from apartment to apartment and be abused by irresponsible householders... ${ }^{19}$

${ }^{15}$ K.A. Tishkina, "Pol'skie organizatsii Barnaula v gody Pervoi mirovoi i Grazhdanskoi voin." In Y.M. Goncharov, and V.N. Shaydyrov et al. Sovremennoe istoricheskoe sibirevedenie XVIII - nachala XX v. Sbornik nauchnykh trudov (St. Petersburg: Mediapapir Publ., 2020), 162-171.

16 "Emissariat Pol'skogo Voennogo Komiteta," Altaiskaia mysl' 23 March, 1919.

${ }^{17}$ Gosudarstvennyi arkhiv Altaiskogo kraia (henceforth GAAK), f. P-9, op. 1, d. 250, 1. 5.

${ }^{18}$ GAAK, f. P-706, op. 1, d. 4, 1. 59.

${ }^{19}$ Ibid., d. 6, 1. 246. 
When regulating such requests, Altgubrevkom (the Altai province revolutionary committee) referred to the decree of the Council of People's Commissars of July 27, 1918 "On the equation of refugees retaining Russian citizenship with respect to jurisdiction with other citizens," according to which

\footnotetext{
...the refugees who did not declare their withdrawal from Russian citizenship $<\ldots>$ will come under the same jurisdiction as the rest of the citizens of the Russian Republic. ${ }^{20}$
}

The refugees were to apply to various social bodies with a request to solve their problems, rather than to the Plenbezh department, which was not competent in these matters.

\section{Repatriating the Poles in 1920-1922}

In February 1920, Tsentroplenbezh was transformed into Tsentrevak (the Central Office for the Evacuation of the Population), which led to renaming its departments of at the local level as well. In Siberia, responsibility for returning refugees and prisoners of war to their homeland rested with the Siberian Office for the Evacuation of the Population (Sibevak) which was subordinate to the Siberian Revolutionary Committee (Sibrevkom). Sibevak's board was located in Novonikolaevsk (now Novosibirsk). The Provincial Offices for the Evacuation of the Population (Gubevak) and the Uezd offices for the Evacuation of the Population (Uevak) were both under Sibv eak's jurisdiction. The employees of Gubevaks and its units were to record, register and send back to their homeland all refugees, military and civilian prisoners, as well as foreign nationals living in the territories under their jurisdiction. ${ }^{21}$ Sibevak's activities extended over Omsk, Tomsk, Semipalatinsk, Altai, Yenisei and Irkutsk provinces. ${ }^{22}$

Operating in Barnaul, in 1921 the Altai Provincial Office for the Evacuation of the Population (Altgubevak) was responsible for two Uevaks - in Biisk and Zmeinogorsk (Rubtsovka station). At the railway stations Barnaul, Biisk and Rubtsovka (the village of Rubtsovo, from 1922 - the town of Rubtsov, now - the town of Rubtsovsk, Altai Territory), there were refreshment stations.

Although the compulsory registration of refugees began in winter 1920, its work was delayed due to the late notification of the uezd and volost executive committees about the requirement and the lack of registration forms at the local level, among other.

In May 1920, the Altai provincial extraordinary commission for combating counterrevolution, speculation and crime sent a decree to the Altai provincial militia ordering

...the immediate registration of citizens of Polish nationality from 16 to 60 years old. ${ }^{23}$

The document added that persons who

...did not fill out the form or provided incorrect and insufficiently complete information will be prosecuted as counter-revolutionaries and spies of the Polish government. ${ }^{24}$

To implement the decree, a special questionnaire was issued asking respondents to indicate when and why they had come to Russia, their workplace, party affiliation, attitude to the Soviet regime, citizenship and the desire to change it, the supposed move to Poland, etc. Most of the Poles who found themselves in Siberia as refugees during the First World War wanted to return to their homeland and obtain citizenship of the new republic.

\footnotetext{
${ }^{20}$ Dekrety Sovetskoi vlasti. Moscow, 1964, vol. 3, p. 103.

${ }^{21}$ GAAK, f. P-706, op. 1, d. 10,1.313.

${ }^{22}$ L.K. Ostrovskii, "Repatriatsiia optantov," 70-74.

${ }^{23}$ GAAK. f. P-9, op. 1, d. 265, 1. 1.

${ }^{24}$ Ibid., d. 50, 1. 127.
} 
In summer 1920, some Polish citizens were detained on charges of counter-revolution. For example, K.A. Kazitskii was placed in a forced labor camp. He had adopted Polish citizenship after the decree of March 20, 1919

...out of fear of being mobilized and thereby becoming an involuntary participant in the fight against Soviet power. ${ }^{25}$

On March 18, 1921 the Soviets concluded their war with Poland by signing the Peace of Riga. The treaty fixed the borders between the erstwhile combatants and stipulated the process of obtaining citizenship on a voluntary basis.

At the end of March 1921, Sibevak issued an order on the registration of refugees from Poland and the western provinces upon presentation of the relevant documents. At the same time, as it noted,

...in the registration form of refugees it is not necessary to indicate either citizenship or nationality, since the territory of Poland is not yet known. ${ }^{26}$

The registration process was to be controlled by the local Gubevaks.

Given the short period for completing the process, a large number of clerks were needed to carry it out. Thus, the Altgubevak's staff numbered 40-55 people, and the Uevaks employed no more than 10 people. As a result, they included even members of the Polish section of the RCP (b) (the Russian communist party of the Bolsheviks) and refugees themselves. Another problem was the lack of the required number of registration forms and paper. For this reason, the registration of refugees from the western provinces was carried out only in the uezd towns of the Altai province. That summer, the Biisk Uevak passed information to Barnaul, according to which in May 1921 2,358 Polish refugees were registered, and in June another 76 people. $^{27}$

After the conclusion of the Soviet-Polish War, refugee families began to arrive from the countryside in the uezd towns and demanded that the local Uevaks immediately register and send them home. ${ }^{28}$ Rumors spread among the refugees that the repatriation process would begin only in the fall, after the harvest. Crowds of migrants settled in towns and refused to return to their settlements. Therefore, that summer Gubevaks explained to the volost and village executive committees that only refugees' re-registration should be carried out locally. It also ordered the authorities to prevent the sale of property and the departure of migrants from the countryside.

Some refugees sent applications to Altgubevak for evacuation to Poland. Thus, at the end of May 1921 it received a registered a letter from L.K. Krasovskii who lived in Zmeinogorsk. He pointed out that before being evacuated to Siberia he had worked at the Murovanka cork factory in Minsk province. According to him, the factory was located $23 \mathrm{~km}$ from the village of Filippovichi through which the Polish border line passed. Krasovskii's wife and daughter had stayed behind in Minsk, but in 1920 they moved to Poland. On these grounds, he asked for assistance in reuniting his family and obtaining, together with his son, passes for leaving for Poland. After the registration procedure in May 1921, the Krasovskiis filed applications to resign from their positions. ${ }^{29}$

By the middle of the summer, Uevaks sent details about the territories that belonged to Poland to their branches. Those eligible to obtain Polish citizenship had to pre-

\footnotetext{
${ }^{25}$ GAAK, f. P-9, op. 1, d. 50, 1. 127.

${ }^{26}$ Ibid., f. P-45, op. 1, d. 6, 1. 4.

${ }^{27}$ Ibid., f. P-706, op. 1, d. 10, 1. 280.

${ }^{28}$ Ibid., d. 15, k. 18.

${ }^{29}$ Ibid., f. P-663, op. 3, d. 1, 1. 22.
} 
sent documents confirming their residence before August 1, 1914 in Warsaw, Kalisz, Kielce, Lublin, Lomza, Plock, Piotrkow, Radom, Siedlce, Chelm, Suwalki (Suwalk and Augustow Uezds), Grodno (except for the town of Grodno and Grodnensky Uezd), Minsk (Pinsk and Novogrudsky Uezds), Volinsky (Volodymyr-Volynskyi, Kovel, Dubensky, Rivne, Kremenets, Lutsk and Ostrozhsky Uezds). The Altgubevak estimated that by December 1921 9,498 Polish refugees had been registered. ${ }^{30}$

Even some Belarusian refugees now turned out to be Polish citizens according to where they had lived before the war. For example, in April 1923 the right to leave the Shipunovskii volost of Altai province was given to the members of the Romaniuk family, who had previously lived in Minsk province in the village of Nevda, and members of the Lutsik family, who had lived in Grodno province in the village of Orekhovo. ${ }^{31}$

In fall 1921, local provincial executive committees began to accept applications from "...Polish natives for the option ${ }^{32}$ of citizenship in favor of Poland." All interested persons were invited to fill in the forms and questionnaires in duplicate and submit them along a passport or birth certificate; or, if neither were available - a record of service, a secondary school certificate, an official list, etc. One copy of the application was to be sent to the NKVD (People's Commissariat for Internal Affairs), the other - to the office of Poland's representative in Siberia.

In March 1922, an advertisement appeared in the supplement to Krasny Altai: "To Those Eligible for Polish Citizenship" from K. Gintovt, the Commissioner for Receiving Applications Polish Citizenship. It stated that all applications for citizenship were to be submitted simultaneously no later than July 30, 1922 to the office of Poland's representative in Siberia, the representative office of the Russian-Ukrainian-Polish Mixed Commission on Repatriation Affairs and to the management department of the local executive committee. The documents submitted to the former were to be originals along with a photograph of the applicant along with those of any family members over the age of $14 .^{33}$

If the application were rejected for any reason, the applicant could appeal this decision through the Ministry of Foreign Affairs of Poland. Persons who received permission to obtain Polish citizenship had the right to leave for the republic. However, as Gintovt's ad cautioned,

...due to transport problems in Russia, both the departure and the very option that requires relations with Moscow, and in some cases <...> with Poland, will inevitably be slowed down, and therefore applicants should refrain from liquidating their property until receiving a positive reply and time of departure. ${ }^{34}$

\section{The results}

According to the report on the activities of the Office of the Special plenipotentiary of Tsentraevak in Siberia, as of January 1, 1922, based on incomplete data, there were 780,850 Poles in Siberia. ${ }^{35}$ By the end of 1921 , about $25 \%$ of the repatriates were back in their homeland. There were plans to send 2,528 Poles from Biisk Uezd in two echelons. The first was to leave on November 10, 1921 from Biisk station, and the second one - on November 15 from Bolshaia Rechka station. ${ }^{36}$

${ }^{30}$ GAAK, f. P-663, op. 3, d. 15, 1. 29.

${ }^{31}$ Ibid., f. P-706, op. 1, d. 27, 1. 107.

32 Option in international law - the choice of citizenship by persons with dual nationality, or living in a territory that has changed its affiliation with a country.

${ }^{33}$ E.V. Shcherbakova, "Zakonodatel'naia reglamentatsiia optatsii grazhdanstva (1920-1922 gg.)." Leningradskii iuridicheskii zhurnal, no. 2 (2012): 201-20.

34 “Obiavlenie," Supplement to Krasnyi Altai. 12 March 1922.

${ }^{35}$ State Archive of the Novosibirsk oblast, f. P-2111, op. 1, d. 5, 1. 17.

${ }^{36}$ GAAK, f. P-760, op. 1, d. 10, k. 520 obverse. 
Evacuations were halted that winter due to the lack of transport and the poor condition of the railroad tracks. The arrival of "famine-refugees" from European Russia also complicated matters. The operation was partially restored in April 1922. According to the estimates of one researcher, L.K. Ostrovskii, 36,404 Polish refugees left Siberia between July 1921 and January 1923. ${ }^{37}$

The end of the mass repatriation to Poland was announced in 1924. All Polish repatriates, regardless of their place of residence, were to apply to the Polish embassy in Moscow by November 15, 1924 to obtain an exit visa. The documents confirming the right to leave the USSR were to include an explanatory note on the reasons why a person had not left earlier. ${ }^{38}$ However, repatriation lasted until 1925. Thus, in May 1925, the Biisk Uezd executive committee carried out an urgent registration of refugees who wished to leave for Poland. Those migrants registered by the local Uevak, but removed from the register due to the lack of necessary documents, did not need to register. ${ }^{39}$

\section{Conclusion}

The repatriation of Polish refugees who settled in Siberia during World War I was carried out in the difficult conditions of the years after the Civil War and the economic crisis. Despite the creation of a whole network of bodies to control the evacuation, their work was severely hampered due to poor information of the center, the small number of employees, and the shortage of registration forms, among other. Many refugees left their settlements without permission, which complicated gathering an accurate count. In addition, some documents betrayed official fears that the outflow of the peasant population from the sparsely populated territory of Siberia might affect the country's economy, especially due to the poor harvest in the Volga region. Groups of forced migrants mostly left in late autumn, after the harvest.

Поступила в редакцию / Submitted: 21.03.2021

Одобрена после рецензирования / Approved after reviewing: 06.09.2021

Принята к публикации / Accepted for publication: 04.10.2021

\section{References}

Belova, I.B. "Bezhentsy Pervoi mirovoi voiny v Sovetskoi Rossii 1918-1919 gg." Gumanitarnye nauki v Sibiri, no. 3 (2014): 32-36 (in Russian).

Belova, I.B. "Polozhenie bezhentsev Pervoi mirovoi voiny v Sovetskoi Rossii: 1921 g." Istoricheskie, filosofskie, politicheskie $i$ yuridicheskie nauki, kul'turologiya i iskusstvovedenie. Voprosy teorii i praktiki, no. 4-2 (18). (2012): 26-29 (in Russian).

Belova, I.B. Vynuzhdennye migranty: bezhentsy $i$ voennoplennye Pervoi mirovoi voiny v Rossii. 1914-1925. Moscow: AIRO-XXI Publ., 2014 (in Russian).

Gatrell, P. "Refugee history and refugees during and after the First World War." Vestnik of Saint Petersburg University. History 62, no. 3 (2017): 497-521. DOI: 10.21638/11701/spbu02.2017.305

Gonczarow, Jurij M. "Polska rodzina na Syberii w połowine XIX i na początku XX wieku." Zestaniec, no. 29 (2007): 33-48 (in Polish).

Lakhareva, N.V. Reevakuatsyia bezhentsev Pervoi mirovoi voiny s territorii Kurskoi gubernii (1918-1925). Kursk: KIGMS Publ., 2001 (in Russian).

Nam, I.V. "Pol'skie bezhentsy Pervoi mirovoi voiny v Sibiri." In Pol'skie ssyl'nye v Sibiri vo vtoroi polovine XVIII - nachale XX veka v vospriyatii rossiiskoi administratsii, pereselentsev $i$ korennykh narodov Sibiri. Omsk: Poligraf Tsentr KAN Publ., 2015 (in Russian).

${ }^{37}$ L.K. Ostrovskii, "Migratsiia kak faktor formirovaniya pol'skoi diaspory v Zapadnoi Sibiri. Chislennost' i sostav pol'skogo naseleniya na territorii kraya na rubezhe XIX-XX vv." Istoricheskie, filosofskie, politicheskie $i$ yuridicheskie nauki, kul'turologiya i iskusstvovedenie. Voprosy teorii i praktiki 1, no. 5 (2014): 137-144.

38 “Vnimaniiu pol'skikh bezhentsev," Sovetskaia Sibir'. 4 September, 1924.

39 Ibid. 
Nam, I.V. Natsional'nye men'shinstva Sibiri i Dal'nego Vostoka na istoricheskom perelome (1917-1922 gg.). Tomsk: Tomsk university Pabl., 2009 (in Russian).

Oplakanskaya, R.V. "Deyatel'nost' predstavitel'stva Smeshannoi komissii v Sibiri po repatriatsii pol'skikh voennoplennykh v 1921 godu." Tomskii zhurnal LING i ANTR, no. 3 (2015): 120-127 (in Russian).

Ostrovskii, L.K. "Migratsiya kak faktor formirovaniya pol'skoi diaspory v Zapadnoi Sibiri. Chislennost' i sostav pol'skogo naseleniya na territorii kraya na rubezhe XIX-XX vv." Istoricheskie, filosofskie, politicheskie i yuridicheskie nauki, kul'turologiya i iskusstvovedenie. Voprosy teorii i praktiki I, no. 5 (2014): 137-144 (in Russian).

Ostrovskii, L.K. "Repatriatsiya optantov, bezhentsev i voennoplennykh iz Sibiri v Pol'shu (1921-1924 gg.)." Gumanitarnye nauki v Sibiri, no. 3 (2014): 70-74 (in Russian).

Ostrovskii, L.K. "Repatriatsiya optantov, bezhentsev i voennoplennykh iz Sibiri v Pol'shu (1921-1924 gg.)." Gumanitarnye nauki v Sibiri, no. 3 (2014): 70-74 (in Russian).

Ostrovskii, L.K. Polyaki v Zapadnoi Sibiri v kontse XIX-pervoi chetverti XX veka. St. Petersburg: Aleteiya Publ., 2018 (in Russian).

Shaidurov, V.N. "Ethnic Entrepreneurship in the Russian Empire in the Era of Economic Modernization in the Second Half of the $19^{\text {th }}$ - Early $20^{\text {th }}$ Century (as Illustrated in the Example of Siberia)." Bylye gody, no. 41-1 (3) (2016): 666-674.

Shaidurov, V.N. "On the emerging polish diaspora and its development in Siberia in the first half of the $19^{\text {th }}$ century." Journal of Siberian Federal University. Humanities \& Social Sciences, no. 10 (2016, 9): 2496-2506. DOI: 10.17516/1997-1370-2016-9-10-2496-2506

Shaidurov, V.N. "The Polish community in Western Siberia: Adaption and integration features in the second half of the $19^{\text {th }}$ century." Acta Histriae 26, no. 2 (2018): 641-660, DOI 10.19233/AH.2018.26

Shcherbakova, E.V. "Zakonodatel'naya reglamentatsiya optatsii grazhdanstva (1920-1922 gg.)." Leningradskii yuridicheskii zhurnal, no. 2 (2012): 201-206 (in Russian).

Shostakovich, B.S. "Sistemnaya sibirsko-pol'skaya istoriya - sovremennaya kon-tseptual'naya al'ternativa marginal'no-traditsionalisticheskogo diskursa istorii polyakov v Sibiri." In Pol'skie ssyl'nye v Sibiri vo vtoroi polovine XVIII - nachale XX veka v vospriyatii rossiiskoi administratsii, pereselentsev $i$ korennykh narodov Sibiri, 10-22. Omsk: Poligraf tsentr KAN Publ., 2015 (in Russian).

Skubnevskii, V.A., and Goncharov, Yu.M. "Polyaki v Sibiri (XIX - nachala XX v.) v osveshchenii postsovetskoi otechestvennoi istoriografii." Vestnik Tomskogo gosudarstvennogo universiteta. Istoriya, no. 69 (2021): 162-170. DOI: 10.17223/19988613/69/24 (in Russian).

Sula D. Powrót ludności polskiej: z byłego Imperium Rosyjskiego w latach 1918-1937. Warsaw: Trio Publ., 2013 (in Polish).

Tishkina, K.A. "Pol'skie organizatsii Barnaula v gody Pervoi mirovoi i Grazhdanskoi voin.” In Goncharov, Y.M., and Shaydyrov, V.N. eds. Sovremennoe istoricheskoe sibirevedenie XVIII - nachala XX v. Sbornik nauchnykh trudov, 162-171. St. Petersburg: Mediapapir Publ., 2020 (in Russian).

\section{Информация об авторах / Information about the authors}

Ю.М. Гончаров, доктор исторических наук, профессор, профессор кафедры отечественной истории Алтайского государственного университета, 656049, Россия, Барнаул, пр. Ленина, 61, yuriig@yandex.ru

К.А. Тишкина, кандидат исторических наук, научный сотрудник научно-исследовательской части Сибирского федерального университета, 660041, Россия, Красноярск, пр. Свободный, 79, ksetishkina@mail.ru
Yu.M. Goncharov, Dr. Habil. Hist., Professor, Professor of the Department of Russian History, Altay State University, 61, Lenin St., Barnaul, 656049, Russia, yuriig@yandex.ru

K.A. Tishkina, Ph.D. in History, Researcher of the Research Department, Siberian Federal University, 79, Svobodny St., Krasnoyarsk, 660041, Russia,ksetishkina@mail.ru 